\title{
Comparison of Dissolved Organic Carbon Bioavailability from Native and Invasive Vegetation along a Hawaiian River ${ }^{1}$
}

\author{
Tracy N. Wiegner ${ }^{2,4}$ and Randee L. Tubal ${ }^{3}$
}

\begin{abstract}
Riparian litter fall is an important source of organic matter to rivers and accounts for a large fraction of their dissolved organic carbon (DOC) load. DOC is metabolically important in rivers, and therefore changes in riparian vegetation species composition should affect riverine DOC bioavailability. Worldwide, invasive vegetation composes a large percentage of riparian vegetation. In Hawai' $i$, riparian vegetation changes from native to invasive species with decreasing elevation. To assess how changes in riparian vegetation affect riverine DOC dynamics, we compared DOC bioavailability from native (Acacia koa and Metrosideros polymorpha) and invasive (Falcataria moluccana and Psidium cattleianum) riparian trees to freshwater and estuarine bacteria from the Wailuku River on Hawai'i Island through dark bioassays. DOC bioavailabilities in riverine and estuarine waters were similar among all riparian vegetation types. In contrast, vegetation-derived DOC was more bioavailable $(52 \% \pm 4 \%)$ than the riverine and estuarine DOC $(14 \% \pm 3 \%)$. Combining DOC bioavailability and leaf litter input data from our native and invaded riparian sites suggests that a shift in leaf litter inputs from native to invasive species may increase the amount of bioavailable DOC entering Hawaiian rivers and streams. This DOC input has the potential to impact the metabolism and food webs of downstream ecosystems.
\end{abstract}

LEAF LITTER INPUTS from the riparian zone play a fundamental role in rivers by supplying

\footnotetext{
${ }^{1}$ This research was funded by the Research Enhancement Activities Program (REAP) under NSF Award No. 0237065, Investing in Multidisciplinary University Activities through Hawai'i EPSCoR, and by a grant/ cooperative agreement from the National Oceanic and Atmospheric Administration, Project REIL-38, which is sponsored by the University of Hawai'i Sea Grant College Program, SOEST, under Institutional Grant No. NA050AR4171048 from NOAA Office of Sea Grant, Department of Commerce. The views expressed herein are those of the author(s) and do not necessarily reflect the views of NOAA or any of its subagencies. Manuscript accepted 8 December 2009.

${ }^{2}$ Department of Marine Science, University of Hawai'i, Hilo, Hawai'i 96720.

${ }^{3}$ Master's Program in Tropical Conservation Biology and Environmental Science Program, University of Hawai'i, Hilo, Hawai'i 96720.

${ }^{4}$ Corresponding author (e-mail: wiegner@hawaii .edu).
}

Pacific Science (2010), vol. 64, no. 4:545-555

doi: $10.2984 / 64.4 .545$

(C) 2010 by University of Hawai'i Press

All rights reserved an allochthonous source of carbon (C) and nutrients to their food webs (Wallace et al. 1997, Kennedy and Hobbie 2004). The C and nutrients in leaf litter are available to riverine organisms as either particulate leaf fragments or dissolved substances leached from leaves. In temperate streams, up to $70 \%$ of heterotrophic respiration, which is primarily bacterial, can be supported by dissolved organic C (DOC) leached from leaf litter (Kaplan et al. 2007), and up to $30 \%$ of the DOC exported from these systems has been shown to be derived from riparian leaf litter (Meyer et al. 1998). Findings from these two previous studies, plus the plethora of bioassay experiments examining riverine DOC bioavailability to bacteria (e.g., Servais et al. 1987, Volk et al. 1997), demonstrate that DOC derived from leaf litter is an important $\mathrm{C}$ and energy source for riverine bacteria. To date, most of the research examining the importance of riparian leaf litter as a bioavailable DOC source to riverine heterotrophic bacteria has been conducted in temperate rivers; little is known about the importance of leaf litter as a bioavailable DOC source to tropical river- 
ine heterotrophic bacteria. Tropical rivers differ fundamentally from their temperate counterparts in that they receive a year-round supply of leaf litter inputs (Stout 1980), whereas temperate rivers receive an annual pulse of leaf litter associated with autumn leaf fall (Meyer et al. 1998). In addition, tropical rivers receive year-round fruit inputs, which are high in soluble sugars and may provide a readily bioavailable source of $\mathrm{C}$ to riverine bacteria (Baker et al. 1998, Larned et al. 2001).

Compositional changes to riparian vegetation in both temperate and tropical regions have been shown to dramatically affect riverine organic matter and nutrient dynamics (O'Connor et al. 2000, Compton et al. 2003). In some instances, these changes involve the replacement of native vegetation with invasive vegetation. This may correspond to changes in the quantity and quality of leaf litter falling directly into the river or entering the river after processing in the soil. Regardless of whether the leaves fall into the river or onto the soil first, the replacement of native vegetation with invasive vegetation has the potential to impact the quantity and quality of material entering rivers and hence the organisms that depend on leaf litter as a food source. Numerous studies have demonstrated that invasive vegetation in tropical forests alters nutrient cycling in soils through increased leaf litter inputs to the forest floor (e.g., Vitousek and Walker 1989, Hughes and Denslow 2005). However, only a few studies have addressed the effects of invasive riparian vegetation on organic matter and nutrient dynamics within rivers (O'Connor et al. 2000, Kennedy and Hobbie 2004).

Riparian leaf litter inputs have been linked to in-stream DOC quantity and quality (Meyer et al. 1998, McArthur and Richardson 2002). Therefore, any change associated with a shift in riparian vegetation composition, such as the replacement of native vegetation with invasive vegetation, has the potential to alter riverine DOC dynamics. Tropical riverine ecosystems may be especially sensitive to shifts in vegetation species because vegetation inputs occur throughout the year and leaf decomposition increases with higher water temperatures (Reice 1974). Hawai' $i$ is a prime example in the tropics where native vegetation is actively being replaced by invasive vegetation (Wagner et al. 1999). In Hawai' $i$, the combination of densely vegetated riparian areas coupled with a close proximity to the ocean has the potential to impact DOC dynamics not only in fresh waters, but also in nearshore coastal areas, where terrestrial DOC is more bioavailable (Stepanauskas et al. 1999, Wikner et al. 1999). To date, no studies have examined the effects of invasive riparian species on DOC dynamics in rivers and estuaries in either temperate or tropical regions. The goal of this study was to examine how the replacement of native riparian vegetation with invasive vegetation impacts DOC dynamics in a tropical river system. Although other DOC sources (i.e., benthic algal production, nonpoint and point source inputs, and atmospheric deposition) and riverine processes (i.e., photochemical reactions and sorption) can affect riverine DOC bioavailability, we specifically wanted to examine differences in the bioavailability of DOC derived from both native and invasive riparian vegetation and the implications of those differences to riverine DOC dynamics. To do this, we used dark bioassays comparing the bioavailability of DOC derived from both native and invasive riparian vegetation in both fresh and estuarine waters from a Hawaiian river.

\section{MATERIALS AND METHODS}

\section{Study Site}

Research was conducted on the Wailuku River located on Hawai'i Island, U.S.A. The Wailuku is a perennial river spanning a distance of approximately $40 \mathrm{~km}$, with its headwaters located on the slopes of Mauna Kea and Mauna Loa, and terminating in Hilo Bay; it drains the single largest watershed in the Hawaiian Islands. Riparian vegetation along the Wailuku River changes markedly with elevation; higher elevations $(>500 \mathrm{~m})$ are dominated by native species, and lower 
elevations $(<500 \mathrm{~m})$ are dominated by invasive species, which is typical for vegetation in Hawai'i (Cuddihy and Stone 1990).

We established two sites for this research, which are referred to here subsequently as native and invaded sites. The native site is located at $630 \mathrm{~m}$ elevation within the Hilo Forest Reserve $\left(19^{\circ} 42^{\prime} 48^{\prime \prime} \mathrm{N}, 155^{\circ} 11^{\prime} 56^{\prime \prime} \mathrm{W}\right)$. This site is located within the freshwater portion of the Wailuku River and is predominantly characterized by native vegetation such as Acacia koa (Gray) and Metrosideros polymorpha (Gaud.) (see Table 1). Other native riparian species present in this area but not represented in Table 1 include the tree Cheirodendron trigynum (Gaud.) and the tree fern Cibotium glaucum (Hook \& Arnott). The invaded site is located at $30 \mathrm{~m}$ elevation $\left(19^{\circ}\right.$ $43^{\prime} 32^{\prime \prime} \mathrm{N}, 155^{\circ} 05^{\prime} 30^{\prime \prime} \mathrm{W}$ ) near the mouth of the river, which contains brackish water. The riparian zone of this area is dominated by invasive vegetation consisting primarily of Falcataria moluccana (Nielsen) and Psidium cattleianum (Sabine) (see Table 1). Other tree species present, but not represented in Table 1 include Psidium guajava (Linnaeus), Syzygium jambos (Alston), and Mangifera indica (Linnaeus).

\section{Riparian Tree Species Composition and Litter Collection}

We selected four tree species commonly found in these riparian areas, two native and two invasive, for this study: $A$. koa, M. polymorpha, F. moluccana, and P. cattleianum. Riparian tree species abundances as well as leaf litter and fruit inputs were determined at each site for the four species (see Table 1). Abundance was calculated for an approximate $300-\mathrm{m}$ reach of river using $5 \mathrm{~m}$ wide belt transects placed parallel to the river originating from the vegetation line. Leaf litter and fruit inputs were measured as direct litter fall because this has been shown to be the largest source of leaf litter inputs to Hawaiian rivers (Larned 2000). Leaf litter was collected in $0.16 \mathrm{~m}^{2}$ trays lined with fine-mesh screen ( 1.5 by $2 \mathrm{~mm}$ ) that were placed along the edge of the river above the high-water mark for approximately 2-week intervals. Leaf litter collection for the two sites occurred from June 2005 to August 2006. After collection, leaf litter was sorted by tree species and dried at $70^{\circ} \mathrm{C}$ to a constant mass. The $\mathrm{C}$ and nitrogen $(\mathrm{N})$ content of each of the four chosen vegetation species (leaves and fruit) were determined from dried and ground samples (Wiley mill, 40-mesh) using a CHN analyzer (Elemental Combustion System, Costech Instruments).

\section{Dissolved Organic Carbon Preparation}

Five types of DOC were produced from the four riparian tree species: the phyllodes/ leaves of two N-fixing trees, $A$. koa and F. moluccana; the leaves of $M$. polymorpha; and the leaves and fruit of $P$. cattleianum. $\mathrm{N}$-fixing plants were chosen because their foliar C:N tends to be low compared with non-N-fixing plants found in Hawai'i (Scowcroft 1997, Hughes and Denslow 2005), and higher bioavailability has been observed for DOC with lower C:N (Sun et al. 1997, Hunt et al. 2000). Psidium cattleianum fruit was also used to make DOC because they contain simple sugars (Baker et al. 1998), which are thought to provide a readily labile source of energy and C to aquatic bacteria (Carlson 1993).

DOC was leached from freshly senesced leaves and fruit using a combination of methods to simulate direct leaf litter inputs and mimic natural riverine conditions (Gessner and Schwoerbel 1989, Cleveland et al. 2004, Wiegner et al. 2005). Fruit used to make DOC was harvested directly from trees or off the ground, and freshly fallen leaves were collected with traps, as mentioned earlier. Approximately $3 \mathrm{~g}$ of cut $(<4 \mathrm{~mm})$ plant material was added to 1 liter of sterile filtered reagent-grade water $(0.2 \mu \mathrm{m}$ polycarbonate filters, Osmonics, Inc.) and stirred in the dark for $24 \mathrm{hr}$ at $4^{\circ} \mathrm{C}$. This mixture was then filtered through precombusted $\left(500^{\circ} \mathrm{C}, 6 \mathrm{hr}\right)$ GF/F (Whatman) filters to remove particulate matter and frozen until use in the DOC bioavailability bioassays. Because freshly senesced plant material was used during this process, the dry-weight equivalents of leaf 
and fruit materials used to make the DOC was calculated from wet: dry weight regressions $\left(70^{\circ} \mathrm{C}\right)$ of fruit and leaf samples. All glassware used throughout the DOC preparation and bioavailability experiments was acidwashed and combusted before use.

\section{Dissolved Organic Carbon Bioavailability Experiments}

The bioavailability of DOC leached from the various vegetation species was assessed through dark laboratory bioassay experiments. We minimized potential variation caused from storm inputs of DOC from the watershed by collecting riverine and estuarine waters during base-flow conditions with a depth-integrated sampler (Rickly Hydrology, Columbus, Ohio) in acid-cleaned polypropylene containers. Water samples were stored on ice during transport to the laboratory and filtered through precombusted GF/F filters to remove particulate matter and to eliminate DOC removal from sorption during the experiments, as well as to leave behind some bacteria to serve as an inoculum for the DOC bioavailability experiments (Kaplan et al. 2006).

DOC leached from the various vegetation types was added to duplicate glass flasks with filtered riverine and estuarine waters (described earlier) and incubated in the dark on a shaker table (3 rpm) at close to in situ temperatures $\left(19-24^{\circ} \mathrm{C}\right)$ for 4 days. This length of time was chosen because bacterial growth peaks after a period of 3 days and then decreases (Leff and Meyer 1991). In addition, our experiments were conducted in the dark to minimize any potential photochemical degradation of DOC. Because our goal was to promote Michalis-Menten uptake kinetics of the DOC produced from vegetation, we added DOC to riverine and estuarine waters at concentrations no more than $30 \%$ above base-flow DOC concentrations (Mulholland et al. 2002); control flasks received no DOC additions. Base-flow concentrations of riverine and estuarine DOC were determined before adding DOC derived from vegetation. Water samples were removed daily from each flask, GF/F filtered, and frozen pending analysis. The samples were analyzed for DOC (detection limit [d.1.] $10 \mu \mathrm{mol}$ liter ${ }^{-1}$ ) and total dissolved N (TDN) (d.l. 1 $\mu$ mol liter ${ }^{-1}$ ) on a Shimadzu TOC-V CSH, TNM-1 (Shimadzu Scientific Instruments, Columbia, Maryland), and for $\mathrm{NH}_{4}^{+}$(d.l. 1 $\mu$ mol liter ${ }^{-1}$; USGS method I-2525-89) and $\mathrm{NO}_{3}^{-}+\mathrm{NO}_{2}^{-}$(d.l. $0.1 \mu \mathrm{mol}$ liter $^{-1}$; USEPA method 353.2) on a Technicon Pulse Autoanalyzer II. Dissolved organic N (DON) was calculated by subtracting the dissolved inorganic $\mathrm{N}\left(\mathrm{NO}_{3}^{-}+\mathrm{NO}_{2}^{-}+\mathrm{NH}_{4}^{+}\right)$from $\mathrm{TDN}$ concentrations. DOC bioavailability was determined through the maximum measured decreases in DOC concentration over the course of the experiment and is expressed as percentage bioavailable DOC (maximum measured decrease in DOC concentration divided by the initial DOC concentration), which is the most common method for determining and expressing DOC bioavailability to heterotrophic bacteria (reviewed in del Giorgio and Davis [2003], Wiegner and Seitzinger [2004]). It is assumed that the majority of DOC removal in these experiments was biological from heterotrophic bacteria, because the water was filtered before the experiments (no sorption and no nuclei for flocculate formation), removal by flocculation in estuarine waters at the salinity of water used in these experiments ( $\sim 24 \mathrm{ppt})$ has been shown to be minimal (Sholkovitz 1976), and no flocculates were observed in the flasks. The fate of the DOC taken up by the bacteria within these experiments is beyond the scope of this study, as no bacterial production and/or respiration rates were made.

\section{Statistical Methods}

A comparison of DOC bioavailability between the controls and vegetation-derived DOC addition treatments was performed using a Mann-Whitney $U$ test. Differences in DOC bioavailability for the various vegetation types were analyzed using a two-way analysis of variance (ANOVA) with vegetation species and water type as factors. Data that did not meet the equal variance and normality assumptions for ANOVA analysis were arcsine transformed. Before statistical analy- 
sis, river and estuary DOC contributions were subtracted from the treatments receiving vegetation-derived DOC additions. The $\alpha$-level for all statistical tests was .05. All statistical analyses were performed using SYSTAT 11 software.

\section{RESULTS}

\section{Riparian Tree Species Composition and Litter Collection}

The abundance of the four vegetation species chosen for analysis varied between the native and invaded sites, with $P$. cattleianum being present at both sites (Table 1). Acacia koa was the most abundant tree species at the native site, composing approximately one-third of the vegetation present. At the invaded site, a combination of $F$. moluccana and $P$. cattleianum composed approximately one-third of the vegetation present (Table 1). Leaf litter inputs from the native and invaded sites were approximately six to nine times lower than leaf litter values reported for a lowerorder Hawaiian stream during drought conditions (Larned 2000); Larned's (2000) values may be greater than ours because lower-order

TABLE 1

Relative Abundance of Riparian Vegetation and Leaf Litter Inputs for Native and Invasive Vegetation Species at Two Study Sites along the Wailuku River, Hawai'i

\begin{tabular}{lrc}
\hline \hline & \multicolumn{2}{c}{ Site } \\
\cline { 2 - 3 } Vegetation Species & Native $^{a}$ & Invaded $^{b}$ \\
\hline Percentage relative & & \\
$\quad$ abundance (mean $\pm \mathrm{SE})$ & & \\
A. koa & $35 \pm 4$ & $0 \pm 0$ \\
M. polymorpha & $11 \pm 4$ & $0 \pm 0$ \\
F. moluccana & $0 \pm 0$ & $17 \pm 5$ \\
P. cattleianum & $28 \pm 7$ & $20 \pm 7$ \\
Others & $26 \pm 5$ & $62 \pm 11$ \\
Leaf litter input $\left(\mathrm{g} \mathrm{m}^{-2} \mathrm{yr}^{-1}\right)$ & & \\
A. koa & 13.87 & 0.00 \\
M. polymorpha & 7.67 & 0.37 \\
F. moluccana & 0.00 & 8.76 \\
P. cattleianum & 3.62 & 5.84 \\
Others & 14.24 & 48.00 \\
\hline
\end{tabular}

${ }^{a}$ Sixty-four leaf litter trays were collected at this site.

${ }^{b}$ Sixty leaf litter trays were collected at this site. streams have more direct litter fall inputs (Conners and Naiman 1984), and leaf litter inputs to streams from tropical rain forests are greater during droughts (Spain 1984, Larned 2000). Total leaf litter input from all vegetation sources (including others) at the native site was $39.28 \mathrm{~g} \mathrm{~m}^{-2} \mathrm{yr}^{-1}$. Of the riparian species used in this study, leaf litter inputs at the native site were dominated by $A$. koa (55\%) and $M$. polymorpha (30\%) (Table 1). Leaf litter inputs to the invaded site totaled $62.72 \mathrm{~g} \mathrm{~m}^{-2} \mathrm{yr}^{-1}$, with $F$. moluccana and $P$. cattleianum contributing similar percentages (13.79\% and $9.26 \%$, respectively) to the total litter input (Table 1). Leaf litter inputs from $F$. moluccana and P. cattleianum were relatively small compared with the total litter inputs to the invaded site. However, of the four riparian species used in this study, leaf litter from $F$. moluccana and $P$. cattleianum composed $59 \%$ and $40 \%$ of the input at the invaded site, respectively. No $P$. cattleianum fruits were collected in the litter trays at either site although trees were present at both locations (Table 1). It is suspected that rats and wild pigs ate the fruit in the trays before the litter was collected because seeds from the fruit were found in the trays.

C concentrations for litter samples were lowest for $P$. cattleianum leaves, and $A$. koa had the highest concentration of $\mathrm{C}$ per gram of dried leaves (Table 2). There was greater variability in the $\mathrm{N}$ concentration of leaf litter samples, with an eightfold difference in $\mathrm{N}$ concentrations between $P$. cattleianum and $F$. moluccana leaves (Table 2). The values for leaf litter C:N were highly variable, ranging from 13.4 (F. moluccana) to 97.2 (P. cattleianum leaves) (Table 2). However, the C:N for the dried litter followed an expected pattern, whereby the $\mathrm{N}$-fixing species had $\mathrm{C}: \mathrm{N}$ values that were two to five times lower than the non-N-fixing species (Table 2).

\section{Composition of Dissolved Organic Carbon Leached from Riparian Vegetation}

The soluble component of $\mathrm{C}$ obtained from leaf and fruit samples followed a different pattern than the total $\mathrm{C}$ concentration of the litter mentioned earlier. Acacia koa contained 
TABLE 2

Concentrations of Carbon (C) and Nitrogen (N) in Leaf Litter and DOM (DOC, DON) Extracted from Riparian Vegetation Collected along the Wailuku River, Hawai'i

\begin{tabular}{|c|c|c|c|c|c|c|c|c|c|}
\hline \multirow[b]{2}{*}{$\begin{array}{l}\text { Vegetation } \\
\text { Species }\end{array}$} & \multicolumn{5}{|c|}{ Leaf Litter } & \multicolumn{4}{|c|}{ Leaf Litter Solubility } \\
\hline & $\begin{array}{c}\% \mathrm{C} \\
\text { by mass }\end{array}$ & $\begin{array}{c}\mathrm{C} \\
\left(\mu \mathrm{mol} \mathrm{g}{ }^{-1}\right)\end{array}$ & $\begin{array}{c}\% \mathrm{~N} \\
\text { by mass }\end{array}$ & $\begin{array}{c}\mathrm{N} \\
\left(\mu \mathrm{mol} \mathrm{g}^{-1}\right)\end{array}$ & C:N & $\underset{\left(\mu \mathrm{mol} \mathrm{g}^{-1}\right)}{\text { DOC }}$ & $\begin{array}{c}\text { TDN } \\
\left(\mu \mathrm{mol} \mathrm{g}^{-1}\right)\end{array}$ & $\begin{array}{c}\text { DON } \\
\left(\mu \mathrm{mol} \mathrm{g}^{-1}\right)\end{array}$ & DOC:DON \\
\hline A. koa & 50.7 & 42,300 & 1.7 & 1,210 & 35.0 & 3,450 & 99.4 & 86.7 & 39.8 \\
\hline F. moluccana & 47.0 & 39,200 & 4.1 & 2,930 & 13.4 & 4,240 & 86.4 & 77.2 & 54.9 \\
\hline M. polymorpha & 47.0 & 39,200 & 0.8 & 570 & 68.8 & 7,230 & ND & 0.00 & NA \\
\hline $\begin{array}{l}\text { P. cattleianum } \\
\text { leaves }\end{array}$ & 41.6 & 34,700 & 0.5 & 357 & 97.2 & 5,920 & 56.1 & 44.5 & 133 \\
\hline $\begin{array}{l}\text { P. cattleianum } \\
\text { fruit }\end{array}$ & 44.3 & 36,900 & 0.6 & 429 & 86.0 & 15,900 & 209 & 180.3 & 88.2 \\
\hline
\end{tabular}

Note: Values are expressed as $\mu \mathrm{mol}$ per gram of composite dried litter and were obtained using wet: dry weight regressions $\left(70^{\circ} \mathrm{C}\right)$ of freshly senesced litter. ND, not detected; NA, not available.

the lowest amount of soluble C (8\%), and $P$. cattleianum fruit contained the highest amount of soluble C (43\%) (Table 2). Soluble $\mathrm{N}$ was below detection limits for $M$. polymorpha, and $P$. cattleianum fruit had the highest concentration of soluble N (49\%) (Table 2). The soluble $\mathrm{C}$ and $\mathrm{N}$ values obtained in this study tended to be much higher than values reported for alpine and other tropical vegetation (Cleveland et al. 2004). The soluble organic C:N component of the leaves follows the same pattern as leaf litter $\mathrm{C}: \mathrm{N}$, whereby the $\mathrm{N}$-fixing species had lower DOC:DON (Table 2).

\section{Dissolved Organic Carbon Bioavailability Experiments}

DOC bioavailability was significantly higher in the treatments receiving vegetationderived DOC versus the control flasks, which received no DOC additions $(U=38$, $\mathrm{df}=47, P=.001$ ) (Figure 1 ). In contrast, when control values were subtracted, results from a two-way ANOVA suggest that DOC bioavailability was similar among vegetation types $(F=1.917, \mathrm{df}=4, P=.133)$, with no significant effect of water type $(F=2.169$, $\mathrm{df}=1, P=.151)$. In the freshwater experiments, the bioavailability of DOC derived from vegetation ranged from $50 \%( \pm 10 \%)$ (A. $k o a)$ to $63 \%( \pm 8 \%)$ (P. cattleianum fruit) (Figure 2). For the estuarine experiments,
DOC bioavailabilities varied widely, especially between $P$. cattleianum leaves $(20 \%$ $[ \pm 15 \%])$ and fruit $(76 \%[ \pm 10 \%])$ (Figure 2), but were not significantly different among vegetation types.

\section{DISCUSSION}

\section{Dissolved Organic Carbon Bioavailability Experiments}

Contrary to expectation, results from this study indicate that DOC leached from native vegetation had bioavailability similar to that of DOC derived from invasive vegetation. These results suggest that from a qualitative standpoint, invasive riparian vegetation does not adversely affect riverine and estuarine DOC quality in the Wailuku River. The observed similarities in DOC bioavailability may be a result of similarities in chemical composition among the vegetation species used in the experiments. Vegetation species related to one another may be similar with regards to their chemical constituents, influencing their DOC bioavailability. For example, $M$. polymorpha and $P$. cattleianum are in the same family (Myrtaceae), which may have resulted in similar chemical properties of the water-soluble component of $\mathrm{C}$ obtained from these vegetation species (Figure 2) and thus similar DOC bioavailabilities.

Previous studies have used molar C:N as a 


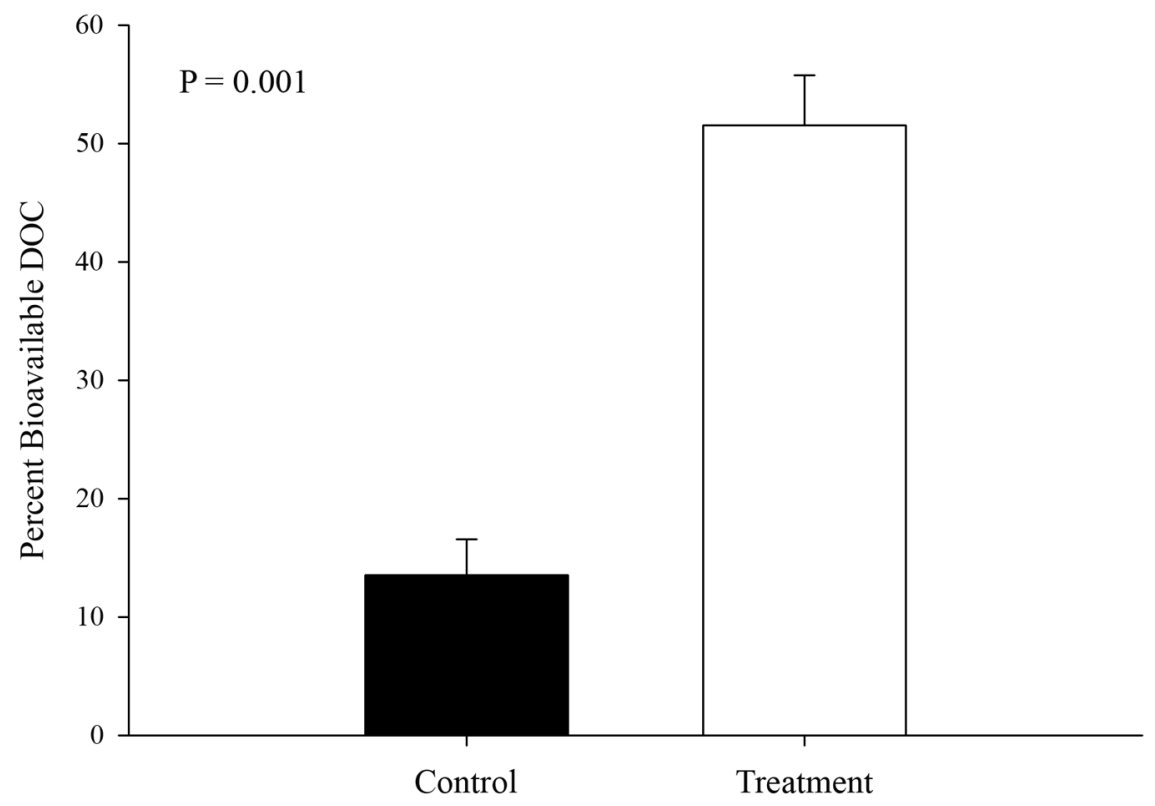

Figure 1. Mean $( \pm \mathrm{SE})$ percentage DOC bioavailability from control and treatment flasks. Controls $(n=8)$ consisted of fresh or estuarine waters with no DOC additions, and treatments $(n=40)$ consisted of fresh or estuarine waters with DOC additions from vegetation-derived sources. The river DOC contribution to the percentage DOC bioavailability for the different vegetation treatments was subtracted from these data. DOC bioavailability was calculated from the maximum difference in DOC concentrations measured during the bioassays. Experiments were conducted using waters collected from the Wailuku River, Hawai'i. $P$ value indicates result from Mann-Whitney $U$ test.

tool to assess and predict the bioavailability of dissolved organic matter (DOM) (e.g., Sun et al. 1997, Hunt et al. 2000). N-fixing species (A. koa and F. moluccana) were selected for this study because it is generally thought that organic molecules with low molar $\mathrm{C}: \mathrm{N}$ are more bioavailable than molecules with high C:N (Sun et al. 1997, McArthur and Richardson 2002). However, results from our study indicate that molar C:N of leaf material was not a good predictor of DOC bioavailability in the river examined here (Table 2). DOC extracted from vegetation is chemically diverse with respect to the functional groups present, and each of these groups differs in their capacity to be broken down by biological processes (Sun et al. 1997, Maie et al. 2006). It is likely that the bulk measurements of DOC performed in this study were not capable of detecting more subtle changes that may have been occurring within the DOC pool. For example, certain functional groups found in DOC molecules, such as amino acids, are thought to be preferentially consumed by bacteria (Benner 2003). However, because the bulk measurements we used in these experiments were not able to distinguish the functional groups present within the DOC pool, there was no way of determining whether certain portions of the DOC pool were being consumed preferentially.

DOM studies conducted in both fresh and estuarine waters have shown that DOM bioavailability is on average 2.4 times higher in estuarine waters (Stepanauskas et al. 1999, Wikner et al. 1999). In contrast, results from our study indicate that DOC bioavailability was similar among riverine and estuarine waters. Some of the increases in bioavailability mentioned in the previous studies likely reflect the degree of DOM degradation in the soil (microbial) and river (microbial and photochemical) before mixing with estuarine waters. If DOC becomes highly degraded and processed by the soil and freshwater mi- 


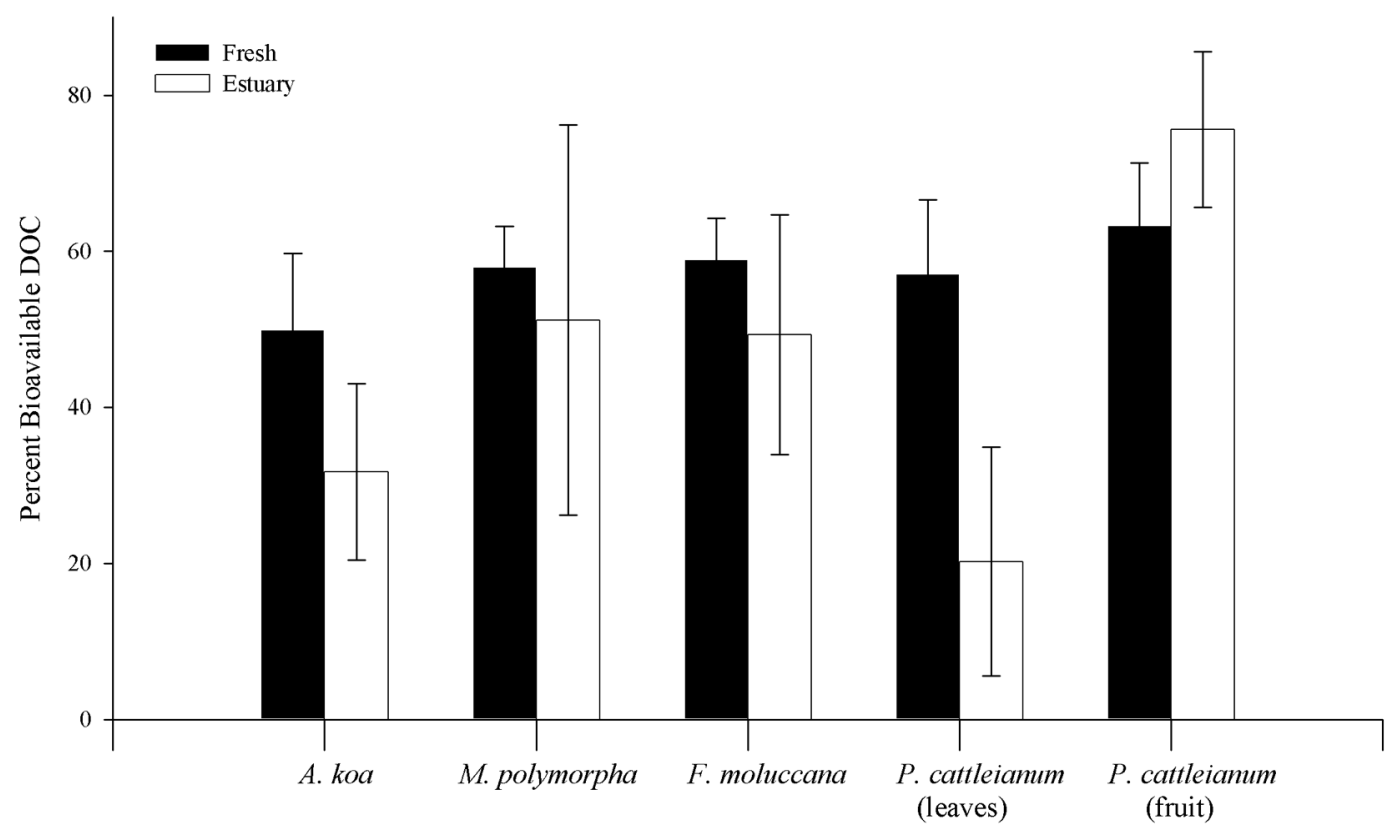

FIGURE 2. Mean $( \pm \mathrm{SE})(n=4)$ percentage DOC bioavailability for experiments conducted with fresh and estuarine waters with DOC additions from vegetation-derived sources. The river DOC contribution to the percentage DOC bioavailability for the different vegetation types was subtracted from these data. DOC bioavailability was calculated from the maximum difference in DOC concentrations measured during bioassays. Experiments were conducted using waters collected from the Wailuku River, Hawai'i. There was no significant difference among DOC bioavailabilities among the different vegetation types examined in either fresh or estuarine waters.

crobes, as well as by photochemical reactions in the river, before entering the estuary, as would be the case for longer, slower-moving rivers, its chemical structure may be altered under higher ionic strengths that render it more bioavailable in the estuarine environment than in the riverine one (Stepanauskas et al. 1999). Because watersheds in Hawai' $i$ are steep and riparian soils are geologically young and well flushed due to large amounts of rain, there may be less time for DOC to be degraded by either soil microbes or in-stream processes before entering the estuary. This could result in little differences in DOC among freshwater and estuarine environments. The lack of microbial processing of the vegetation-derived DOC before interacting with estuarine waters could account for the similarities in DOC bioavailability between riverine and estuarine waters. However, $P$. cattleianum fruit appeared to have a higher bioavailability than its leaves, which could indicate that fruit are an important source of bioavailable DOC, especially to the estuarine portion of the watershed where most of the fruit trees are located.

\section{Implications}

Although there were no qualitative differences among vegetation species and between sites with respect to DOC bioavailability, it seems likely that vegetation species present in riparian areas will impact riverine organic matter dynamics from a quantitative standpoint. Differences in plant life history strategies, such as increased leaf litter production, have the potential to impact riverine DOC dynamics. Invasive riparian vegetation increased allochthonous organic matter inputs to a desert stream by an order of magnitude, dramatically altering leaf litter decomposition and organic matter dynamics within the stream (Kennedy and Hobbie 2004). To as- 
sess the impact of different vegetation types on DOM dynamics in the Wailuku River, we combined leaf litter input values (Table 1) with leaf litter DOC solubility (Table 2) and bioavailability (Figure 2) to calculate the amount of bioavailable DOC (BDOC) entering the river at the invaded site from $F$. moluccana and $P$. cattleianum as compared with M. polymorpha (leaf litter inputs $\left[\mathrm{g} \mathrm{m}^{-2}\right.$ day $\left.^{-1}\right] \times$ leaf litter DOC solubility $[\mu \mathrm{mol}$ DOC $g^{-1}$ leaves] $\times \%$ BDOC). Our calculations suggest that current BDOC inputs from invasive $F$. moluccana $\left(50.2 \mu \mathrm{mol} \mathrm{BDOC} \mathrm{\textrm {m } ^ { - 2 }}\right.$ $\left.\mathrm{day}^{-1}\right)$ and $P$. cattleianum $(19.2 \mu \mathrm{mol}$ BDOC $\mathrm{m}^{-2}$ day $^{-1}$ ) leaf litter are contributing 13 to five times more BDOC than leaf litter inputs from the native $M$. polymorpha $(3.8 \mu \mathrm{mol}$ BDOC $\mathrm{m}^{-2} \mathrm{day}^{-1}$ ). Differences in the amount of BDOC contributed from $F$. moluccana and $P$. cattleianum in comparison with $M$. polymorpha are primarily a function of the amount of leaf litter collected from each tree species at the invaded site (Table 1 ). We recognize that our calculation underestimates the total BDOC inputs from invasive and native species at the invaded site because the species used in the calculation only represents a portion of the total litter input at this site. However, our estimate of BDOC inputs from $P$. cattleianum is an underestimate because fruit inputs were not included, and $\mathrm{C}$ in their fruit was highly soluble and very bioavailable (Table 2 and Figure 2). We compared $F$. moluccana and $P$. cattleianum with $M$. polymorpha because we had leaf litter inputs and DOC bioavailability data for both of those species at the invaded site, and previous work conducted in Hawaiian forests has shown that $F$. moluccana and $P$. cattleianum combined are capable of contributing up to six times more leaf litter than the native M. polymorpha (Hughes and Denslow 2005; R. F. Hughes, unpubl. data). In addition, because most of the river systems in the state of Hawai' $i$ are composed of rivers and streams that are smaller than the Wailuku River and tend to have more canopy cover, the impact of invasive species in these riparian zones may be even greater than suggested by our results. This statement is supported by the fact that the leaf litter input values from this study were approximately six to nine times lower than values reported for lower-order Hawaiian streams (Larned 2000). Although there may not be any qualitative differences in DOC bioavailability among different riparian vegetation species, the invasion of native areas by introduced species such as $F$. moluccana and $P$. cattleianum could result in sustained increases in BDOC inputs to rivers in Hawai'i. Determining the total BDOC loads into systems with more canopy cover, such as is seen on lower-order rivers, is worthy of future investigation.

Sustained increases in the amount of BDOC entering riverine systems in Hawai' ${ }^{i}$ have the potential to affect nutrient and organic matter dynamics, as well as the food webs that depend on riparian vegetation as an energy and nutrient source. Results from this and other studies suggest that vegetation changes in Hawai'i are impacting soils (Vitousek and Walker 1989) and potentially affecting water quality in rivers and estuaries, especially in lower-order rivers. Findings from our study may provide insights into the impacts of invasive riparian trees on DOC dynamics in streams in other regions outside Hawai'i that face similar threats.

\section{ACKNOWLEDGMENTS}

We thank Joshua Uecker, Mark Manuel, Tabitha Van Veen, and Hailey McPhee for invaluable field assistance and support; Hawai' $i$ State Division of Forestry and Wildlife, Dale Nishimoto, Donald Nishioka, and Jack and Jane Stevenson for logistical assistance; Randi Schneider for analytical support; and Rebecca Ostertag, Jene Michaud, and Flint Hughes for comments on early versions of the manuscript.

\section{Literature Cited}

Baker, H., I. Baker, and S. Hodges. 1998. Sugar composition of nectars and fruits consumed by birds and bats in the tropics and subtropics. Biotropica 30:559-586.

Benner, R. 2003. Molecular indicators of the bioavailability of dissolved organic matter. Pages 121-135 in S. E. G. Findlay and 
R. L. Sinsabaugh, eds. Aquatic ecosystems: Interactivity of dissolved organic matter. Academic Press/Elsevier Science, New York

Carlson, C. A. 1993. Production and removal processes. Pages 91-151 in D. A. Hansell and C. A. Carlson, eds. Biogeochemistry of marine dissolved organic matter. Elsevier Science, New York.

Cleveland, C. C., J. A. Neff, A. R. Townsend, and E. Hood. 2004. Composition, dynamics, and fate of dissolved organic matter in terrestrial ecosystems: Results from a decomposition experiment. Ecosystems $7: 275-285$.

Compton, J. E., M. R. Church, S. T. Larned, and W. E. Hogsett. 2003. Nitrogen export from forested watersheds in the Oregon Coast Range: The role of $\mathrm{N}_{2}$-fixing red alder. Ecosystems 6:773-785.

Conners, M. E., and R. J. Naiman. 1984. Particulate allochthonous inputs: Relationships with stream size in an undisturbed watershed. Can. J. Fish. Aquat. Sci. 41:1473-1484.

Cuddihy, L. W., and C. P. Stone. 1990. Alteration of native Hawaiian vegetation: Effects of humans, their activities and introductions. University of Hawai'i Press, Honolulu.

del Giorgio, P. A., and J. Davis. 2003. Patterns in dissolved organic matter lability and consumption across aquatic ecosystems. Pages 399-424 in S. E. G. Findlay and R. L. Sinsabaugh, eds. Aquatic ecosystems: Interactivity of dissolved organic matter. Academic Press/Elsevier Science, New York.

Gessner, M. O., and J. S. Schwoerbel. 1989. Leaching kinetics of fresh leaf-litter with implications for the current concept of leaf-processing in streams. Arch. Hydrobiol. 115:81-90.

Hughes, R. F., and J. Denslow. 2005. Invasion by a $\mathrm{N}_{2}$-fixing tree alters function and structure in wet lowland forests of Hawai'i. Ecol. Appl. 15:1615-1628.

Hunt, A. P., J. D. Parry, and J. HamiltonTaylor. 2000. Further evidence of elemental composition as an indicator of the bioavailability of humic substances to bacteria. Limnol. Oceanogr. 45:237-241.

Kaplan, L. A., J. D. Newbold, D. J. Van Horn, C. L. Dow, A. K. Aufdenkampe, and J. K. Jackson. 2006. Organic matter transport in New York City drinkingwater-supply watersheds. J. North Am. Benthol. Soc. 25:912-927.

Kaplan, L. A., T. N. Wiegner, J. D. Newbold, P. H. Ostrom, and H. Gandhi. 2007. Untangling the complex issue of dissolved organic carbon uptake: A stable isotope approach. Freshwater Biol.: doi:10.1111/j.1365-2427.2007.01941.x.

Kennedy, T. A., and S. E. Hobbie. 2004. Salt cedar (Tamarix ramosissima) invasion alters organic matter dynamics in a desert stream. Freshwater Biol. 49:65-76.

Larned, S. T. 2000. Dynamics of course riparian detritus in a Hawaiian stream ecosystem: A comparison of drought and post-drought conditions. J. North Am. Benthol. Soc. 19:215-234.

Larned, S. T., C. Chong, and N. Punewai. 2001. Detrital fruit processing in a Hawaiian stream ecosystem. Biotropica 33:241248.

Leff, L. G., and J. L. Meyer. 1991. Biological availability of dissolved organic carbon along the Ogeechee River. Limnol. Oceanogr. 36:315-323.

Maie, N., R. Jaffe, T. Miyoshi, and D. Childers. 2006. Quantitative and qualitative aspects of dissolved organic carbon leached from senescent plants in an oligotrophic wetland. Biogeochemistry 78:285314.

McArthur, M. D., and J. S. Richardson. 2002. Microbial utilization of dissolved organic carbon leached from riparian litterfall. Can. J. Fish. Aquat. Sci. 59:1668-1676.

Meyer, J. L., J. B. Wallace, and S. Eggert. 1998. Leaf litter as a source of dissolved organic carbon in streams. Ecosystems $1: 240-249$.

Mulholland, P. J., J. L. Tank, J. R. Webster, W. B. Bowden, W. K. Dodds, S. V. Gregory, N. B. Grimm, S. K. Hamilton, S. L. Johnson, E. Marti, W. H. McDowell, J. L. Merriam, J. L. Meyer, B. J. Peterson, 
H. M. Valett, and W. M. Wollheim. 2002. Can uptake length in streams be determined by nutrient addition experiments? Results from an interbiome comparison study. J. North Am. Benthol. Soc. 21:544-560.

O'Connor, P. J., A. P. Covich, F. N. Scatena, and L. L. Loope. 2000. Non-indigenous bamboo along headwater streams in the Luquillo Mountains, Puerto Rico: Leaf fall, aquatic leaf decay, and patterns of invasion. J. Trop. Ecol. 16:499-516.

Reice, S. 1974. Environmental patchiness and the breakdown of leaf litter in a woodland stream. Ecology 55:1217-1282.

Scowcroft, P. G. 1997. Mass and nutrient dynamics of decaying litter from Passiflora mollissima and selected native species in a Hawaiian montane rain forest. J. Trop. Ecol. 13:407-426.

Servais, P. G., G. Billen, and M. C. Hascoët. 1987. Determination of the biodegradable fraction of dissolved organic matter in waters. Water Res. 21:445-450.

Sholkovitz, E. R. 1976. Flocculation of dissolved organic and inorganic matter during the mixing of river water and seawater. Geochim. Cosmochim. Acta 40: 831-845.

Spain, A. V. 1984. Litterfall and the standing crop of litter in three tropical Australian rainforests. J. Ecol. 72:947-961.

Stepanauskas, R., L. Leonardson, and L. J. Tranvik. 1999. Bioavailability of wetlandderived DON to freshwater and marine bacterioplankton. Limnol. Oceanogr. 44:1477-1485.

Stout, J. 1980. Leaf decomposition rates in Costa Rican lowland tropical rainforest streams. Biotropica 12:264-272.
Sun, L., E. M. Perdue, J. L. Meyer, and J. Weiss. 1997. Use of elemental composition to predict bioavailability of dissolved organic matter in a Georgia river. Limnol. Oceanogr. 42:714-721.

Vitousek, P. M., and L. R. Walker. 1989. Biological invasion by Myrica faya in Hawaii: Plant demography, nitrogen fixation, ecosystem effects. Ecol. Monogr. 59:247265.

Volk, C. J., C. B. Volk, and L. A. Kaplan. 1997. Chemical composition of biodegradable dissolved organic matter in streamwater. Limnol. Oceanogr. 42:39-44.

Wagner, W. L., D. R. Herbst, and S. H. Sohmer. 1999. Manual of the flowering plants of Hawai'i. Vol. 1. University of Hawai'i Press, Bishop Museum Press, Honolulu.

Wallace, J. B., S. L. Eggert, J. L. Meyer, and J. R. Webster. 1997. Multiple trophic levels of a forest stream linked to terrestrial litter inputs. Science (Washington, D.C.) 277:102-104.

Wiegner, T. N., L. A. Kaplan, D. J. Newbold, and P. Ostrom. 2005. Contribution of dissolved organic $\mathrm{C}$ to stream metabolism: A mesocosm study using ${ }^{13} \mathrm{C}$ enriched tree-tissue leachate. J. North Am. Benthol. Soc. 24:48-67.

Wiegner, T. N., and S. P. Seitzinger. 2004. Bioavailability of dissolved organic carbon and nitrogen from pristine and polluted freshwater wetlands. Limnol. Oceanogr. 49:1703-1712.

Wikner, J., C. Rocio, and M. Jansson. 1999. Differences in consumption of allochthonous DOC under limnic and estuarine conditions in a watershed. Aquat. Microb. Ecol. 17:289-299. 
